\title{
龙门山地区的 $\mathbf{P}$ 波速度结构与汶川地震的深部 构造特征
}

\author{
李志伟 ${ }^{(1 *}$, 胥卧 ${ }^{(1)}$, 黄润秋 ${ }^{(2)}$, 郝天珧 ${ }^{(1)}$, 徐亚 ${ }^{(1)}$, 刘劲松 ${ }^{(1)}$, 刘建华 ${ }^{(1)}$ \\ (1) 中国科学院地质与地球物理研究所, 油气资源研究重点试验室, 北京 100029; \\ (2) 成都理工大学地质灾害防治与地质环境保护国家重点实验室, 成都 610059 \\ *E-mail: zwli@mail.iggcas.ac.cn
}

收稿日期: 2010-04-01; 接受日期: 2010-09-10

成都理工大学地质灾害防治与地质环境保护国家重点实验室开放研究基金(编号: DZKJ-0803)资助

\begin{abstract}
摘要 利用四川地震台网 2000 年 1 月 2008 年 4 月的地震数据, 使用地震层析成像方法反 演了龙门山及其邻近地区的地壳 $\mathrm{P}$ 波速度结构, 以此为依据分析了龙门山断裂带和汶川 $M_{\mathrm{s}} 8.0$ 地震的深部构造特征. 研究结果表明, 龙门山的地壳速度结构和深部动力学性质与汶川 $M_{\mathrm{s}} 8.0$ 地震的破裂起始点、震源深度以及破裂传播方向密切相关. 龙门山西侧的彭灌杂岩体是地壳 内部应变强度较大、易于应力长期积累的主要载体, 汶川 $M_{\mathrm{s}} 8.0$ 地震即位于彭灌杂岩体的南端, 毗邻四川盆地的西部边缘, 该块体与四川盆地地壳的碰撞是引发汶川 $M_{\mathrm{s}} 8.0$ 地震的直接原因. 在汶川以北, 沿着龙门山断裂的高速异常有利于破裂的发生和传递, 而汶川以南地壳强度相 对较弱, 不易产生脆性破裂而引发地震, 这可能是地震破裂自汶川向东北方向延伸、汶川以南 缺少地震活动的重要原因. 汶川 $M_{\mathrm{s}} 8.0$ 地震的深部动力成因与龙门山断裂两侧的构造差异有 关, 松潘-甘孜造山带中下地壳强度较弱, 青藏高原的向东运动受到四川盆地刚性岩石层阻碍, 迫使龙门山发生垂向变形, 中下地壳厚度增加, 莫霍面弯曲下沉, 基底则禇皱抬升向山前盆 地逆冲, 地壳形变所产生的应力积累为汶川地震的发生提供了深部动力来源.
\end{abstract}

关键词 龙门山断裂带 汶川地震 $\mathrm{P}$ 波速度 地壳结构 层析成像
龙门山断裂带位于青藏高原的东部边缘, 是松 潘-甘孜造山带与四川盆地的构造分界. 该断裂带于 2008 年 5 月 12 日发生汶川 $M_{\mathrm{s}} 8.0$ 地震(以下称为汶川 地震), 巨大的地震破裂引起地球科学家的极大关注. 龙门山断裂带发育于古老的高强度变质杂岩带中, 主要由三条北东走向的断裂组成, 自西向东分别是 汶川-茂县断裂、映秀-北川断裂和灌县-江油断裂(图 1)，其中映秀-北川断裂被认为是汶川地震的发震断 裂. 上述断裂的深度达到 $20 \mathrm{~km}$ 左右并收玫于地壳
20 30 $\mathrm{km}$ 深度的水平剪切带, 是控制龙门山地壳浅 部推覆体向山前逆冲的主要构造 ${ }^{[2 \sim 4]}$. 龙门山断裂带 东西两侧不仅存在数千米的地势高差, 地壳厚度也 从四川盆地的 $42 \mathrm{~km}$ 左右增厚至青藏高原东缘的近 $60 \mathrm{~km}^{[5,6]}$, 地形和地壳厚度的巨大差异表明龙门山地 区发生了强烈构造变形, 其动力学原因与青藏高原 的向东运动受到四川盆地刚性岩石层的阻挡有关 ${ }^{[4]}$. 甚长基线干涉测量(VLBI)和 GPS 的观测结果证实, 龙门山断裂带新生代以来滑动速率和青藏高原东部

英文引用格式： Li Z W, Xu Y, Huang R Q, et al. Crustal P-wave velocity structure of the Longmenshan region and its tectonic implications for the 2008 Wenchuan earthquake. Sci China Earth Sci, 2011, doi: 10.1007/s11430-011-4177-2 


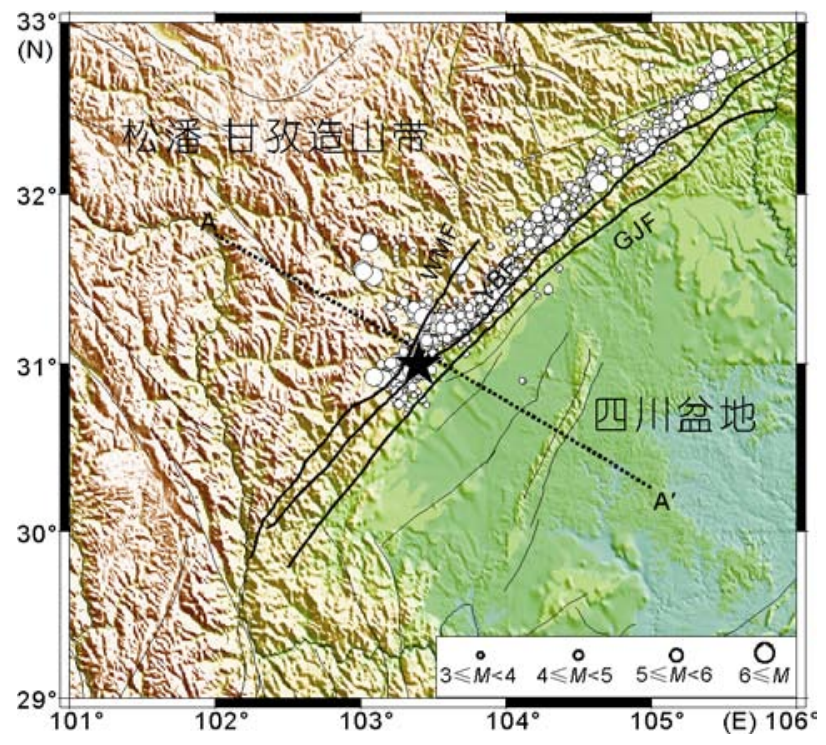

图 1 龙门山断裂带和汶川地震的震中分布

WMF，汶川-茂县断裂; YBF，映秀-北川断裂; GJF，灌县-江油断裂; 星号代表汶川地震的位置, 白色圆点代表汶川地震重新定位后的余

震分布, 其大小则代表余震的震级, 余震数据来自文献[1]

相对于四川盆地的地壳缩短量都很小, 地壳变形主 要发生在垂直方向 ${ }^{[7 \sim 9]}$. 中国地震台网测定的汶川地 震的震源深度约为 $14 \mathrm{~km}$, 双差地震定位的结果为 16 18 $\mathrm{km}^{[1,10]}$, 震源破裂过程的研究也表明中央断裂 的断层面在 $15 \mathrm{~km}$ 深度上发生了错动, 这些研究均表 明地震破裂已经深至中地壳 ${ }^{[1]}$, 因此汶川地震的发 生应该存在深层次的动力学成因.

震后地质调查和震源破裂机制研究表明，汶川 地震从映秀到北川沿着龙门山中央断裂带产生长约 $300 \mathrm{~km}$ 的破裂面, 龙门山前的江油-灌县断裂的破裂 长度也达到 $60 \mathrm{~km}$ 左右 ${ }^{[3,11]}$. 但是地震破裂主要分布 在汶川以北的龙门山断裂带, 并没有继续向南延伸; 大部分余震也发生在汶川及其以北地区, 汶川以南 的龙门山地区地震活动则比较平静. 为何汶川地震 的破裂起始于汶川附近? 为何地震破裂仅仅向北传 递而没有向南延伸? 地震的发生和破裂的传播与龙 门山断裂的地壳结构存在何种联系? 这些问题对于 探索汶川地震的发震机制和深部动力学过程具有重 要意义.

汶川地震发生后，一些学者利用地震层析成像 和远震接收函数方法分析了龙门山地区的壳幔波速 结构和汶川地震的深部构造成因 ${ }^{[5,12 ~ 16]}$. 为了进一步 确定汶川地震的发震构造特征及其与龙门山断裂带
地壳结构的内在联系, 本文利用四川地震台网的地 震数据使用体波地震层析成像方法反演了龙门山及 其邻近地区的地壳 P 波速度结构, 结合余震分布和相 关研究结果探讨龙门山断裂带的深部构造和汶川地 震的形成机制.

\section{1 数据和方法}

\section{1 数据}

本文的研究区域位于龙门山断裂带及其邻近地 区，由于反演地壳深部的速度结构需要利用较长路 径的地震射线，故将收集数据的范围扩大到 $100^{\circ}$ $107^{\circ} \mathrm{E}, 28^{\circ} \sim 34^{\circ} \mathrm{N}$. 另外考虑到汶川地震发生之后地 壳结构的变化可能对地震波的走时产生影响, 加之 汶川地震序列主要集中在龙门山断裂带, 故反演时 仅使用了四川地震台网 2000 年 1 月 2008 年 4 月(汶 川地震之前)的观测数据. 为了确保地震数据的可靠 性, 仅挑选出具有较高精度的 P 波初至到时, 包括直 达 P 波、Pg 波和 Pn 波等多种震相. 每个地震至少有 5 个以上的到时记录，走时残差小于 $3.5 \mathrm{~s}$. 经过挑选 共有 7252 个地震的 68814 个初至 P 波到时参与反演, 地震震中和台站的分布如图 2 所示. 大部分地震和台 站位于松潘-甘孜以及川滇西部造山带，四川盆地内

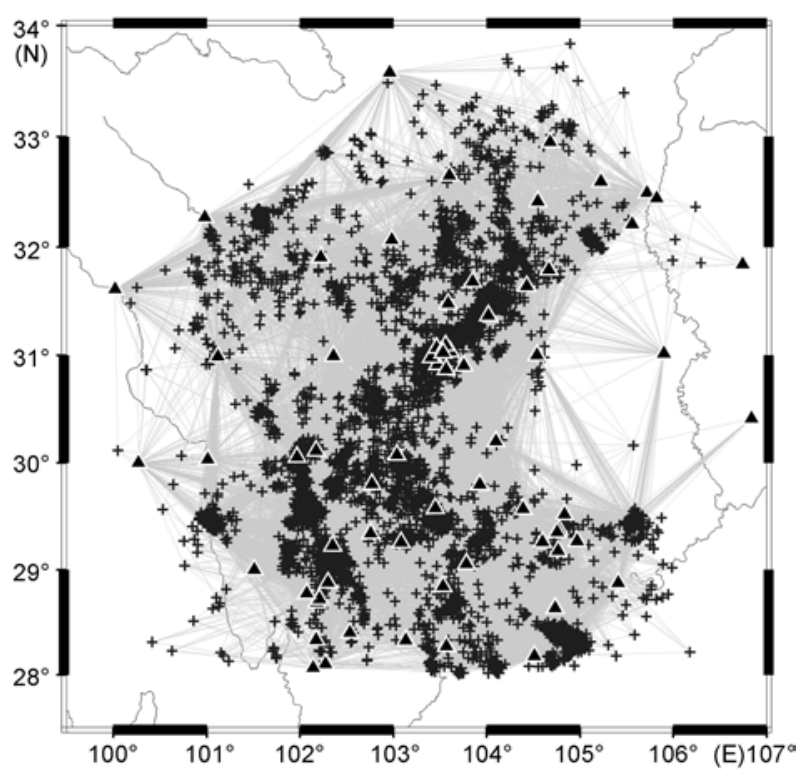

图 2 地震、台站和地震射线分布

黑色三角代表地震台站, 黑色十字代表地震震中, 灰色线段代表地 震射线 
部相对稀少. 现有地震数据的分布表明使用的地震 资料在龙门山地区具有较好的射线覆盖.

\section{2 初始模型}

龙门山断裂带两侧的松潘-甘孜造山带和四川盆 地的地壳厚度变化较大, 使用简单的一维地壳模型 将偏离真实的波速结构. 因此, 本文首先利用布格重 力异常和调和级数法反演了研究区域的莫霍面深 度 ${ }^{[17 ~ 19]}$, 计算结果反映出龙门山地区莫霍面的变化 趋势(图 3). 另外, 考虑到莫霍面深度存在一定的不 确定性, 故在初始模型中以一个速度梯度带来描述 莫霍面. 构建初始模型时除了引入莫霍面之外, 地壳 内部的界面深度和速度值参考了人工地震测深和以 往地震层析成像等研究结果 ${ }^{[20,21]}$, 进而根据走时残 差的分布调整界面深度和速度值, 使得计算的理论 走时与观测数据相吻合. 经过对比射线覆盖密度以 及不同尺度的分辨测试结果, 确定反演时采用沿经 度和纬度为 $0.125^{\circ} \times 0.2^{\circ}$ 的网格划分, 垂直方向的深 度界面和相应速度如表 1 所示.

\section{3 反演方法}

三维射线追踪和走时计算使用伪弯曲法 ${ }^{[22 ~ 24]}$, 线性方程组的求解采用阻尼最小二乘法(LSQR), 并 同时求解 $\mathrm{P}$ 波速度和震源参数, 以减小震源不确定性 对速度结构的影响. 为了避免射线分布不均和数据

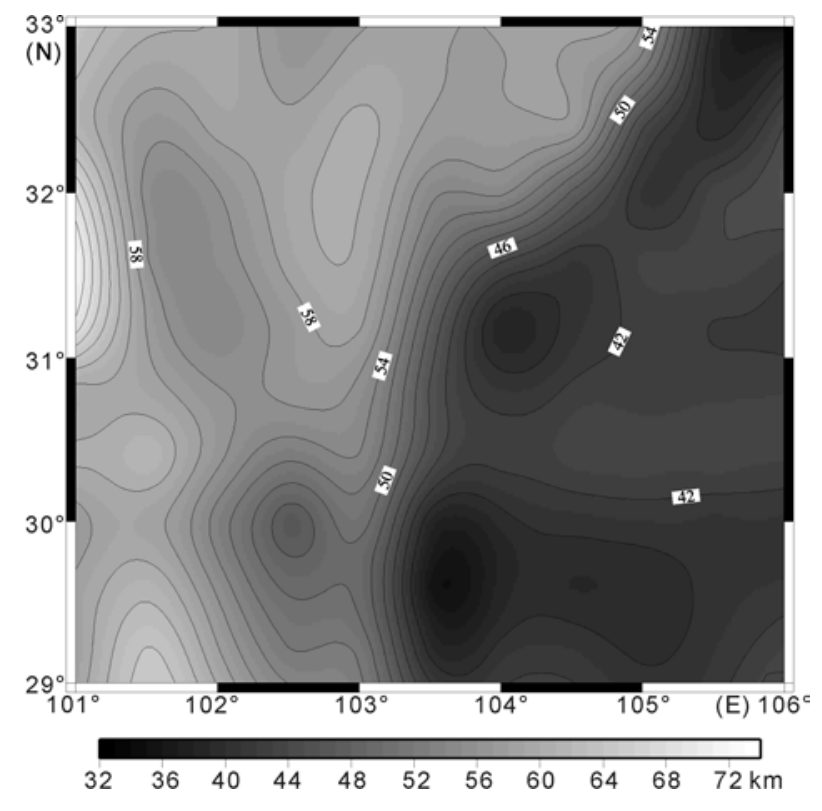

图 3 根据重力异常计算的莫霍面深度分布
表 1 一维 $\mathbf{P}$ 波初始速度模型和深度节点

\begin{tabular}{cc}
\hline 深度 $(\mathrm{km})$ & $\mathrm{P}$ 波速度 $\left(\mathrm{km} \mathrm{s}^{-1}\right)$ \\
\hline 0 & 5.35 \\
5 & 5.45 \\
10 & 5.90 \\
15 & 6.00 \\
20 & 6.15 \\
30 & 6.30 \\
40 & 6.55 \\
53 & 7.80 \\
71 & 8.00 \\
\hline
\end{tabular}

误差对反演结果的影响, 求解线性方程组时引入了 平滑因子以保证解的稳定性, 并采用不同的阻尼因 子和平滑系数进行了多次迭代. 一般情况下, 经过 2 3 次迭代后, 速度异常的变化已经趋于稳定, 走时 残差明显减小, 更多的迭代次数只是速度异常的幅 度有所增加, 而基本样式没有显著变化. 反演后走时 残差的均方差由反演前的 $1.18 \mathrm{~s}$ 降低至反演后的 0.87 $\mathrm{s}$, 表明获取的地壳速度模型和重新定位后的震源参 数能够较好地拟合观测数据.

\section{4 分辨率分析}

分辨率估算采用常用的 Checkerboard 测试板方 法, 初始模型在 $\mathrm{P}$ 波参考速度上添加幅度为 $\pm 4 \%$, 正 负相间的扰动量, 并按照实际的地震-台站分布计算 相应的走时, 构成理论上的观测数据. 然后采用与反 演相同的方法求解, 重建 Checkerboard 速度模型, 并 通过分析速度异常的恢复状况检验地震数据的分辨 能力. 图 4 为 $2 \times 2$ 个网格节点的 Checkerboard 模型恢 复图像, 从各个深度的速度异常恢复情况可以看出, 龙门山及其邻近地区均获得了较好的分辨. 由于天 然地震数据分布的不均匀以及震中距和方位角等因 素限制, 射线的穿透深度和覆盖范围也存在一定的 差异, 分辨范围随着深度的增加从龙门山逐渐扩大 到周围地区，这是由于来自不同方位的地震射线向 台站下方会聚的结果. 总体看来, 基于现有数据的反 演结果能够为分析龙门山地区的地壳结构提供必要 的分辨能力.

\section{2 反演结果}

图 5 给出了 5 40 km 深度的 $\mathrm{P}$ 波速度扰动图像. 为了便于分析速度结构与汶川地震的关系, 我们将 

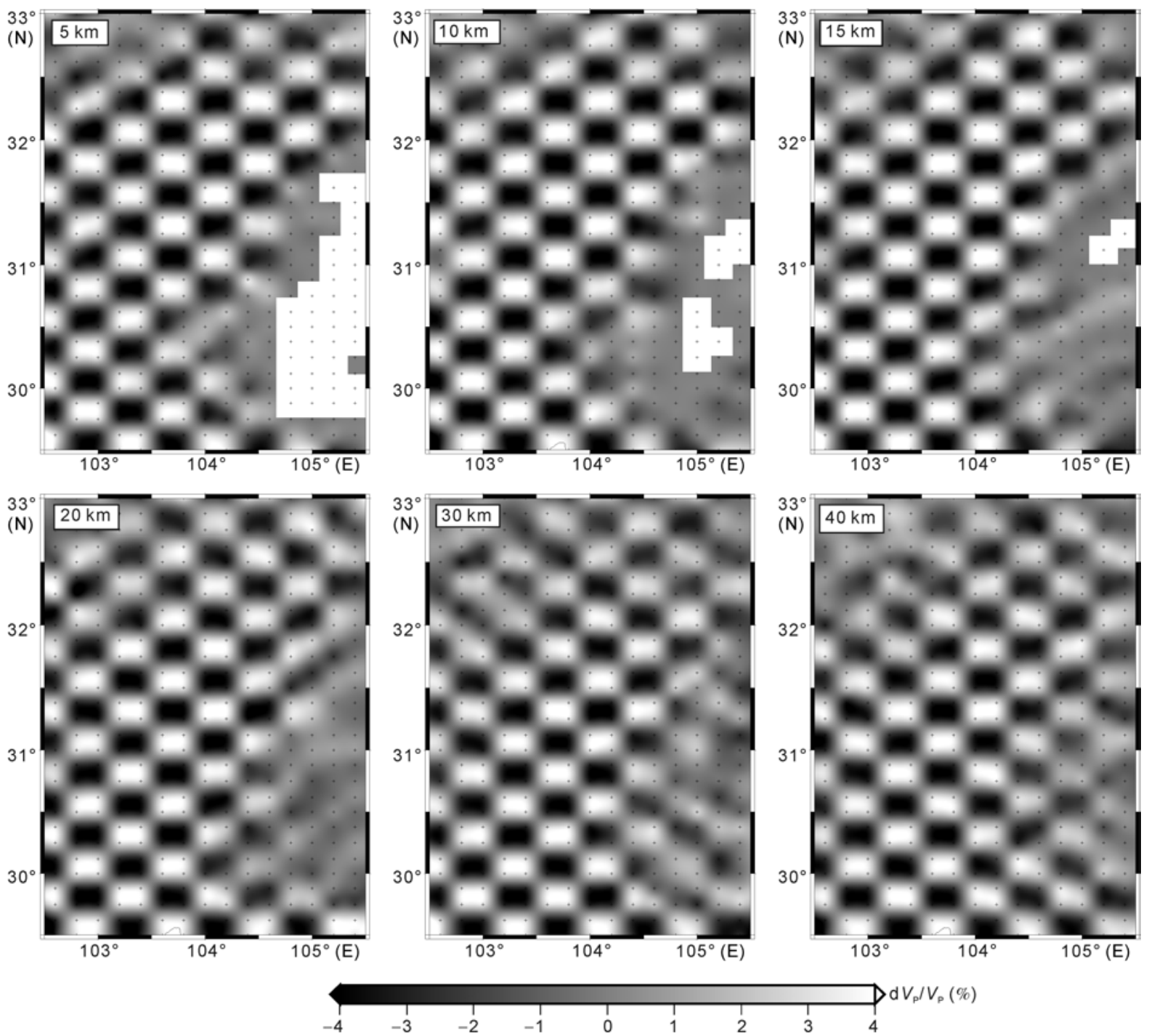

图 4 不同深度 P 波速度结构的 Checkerboard 分辨率测试恢复结果

黑色十字代表反演节点的位置

由双差定位方法重新确定的地震震中 ${ }^{[1]}$ (震源深度误 差小于 $2 \mathrm{~km}$ )投影在相应深度的水平方向 $\mathrm{P}$ 波速度图 像上.

在 $5 \mathrm{~km}$ 深度上, 龙门山断裂带两侧的速度差异 非常明显，松潘-甘孜造山带为高速异常，四川盆地 山前坳陷为低速异常. 两种速度异常的分界自汶川 向北延伸至江油一带, 与龙门山断裂带相吻合, 但是 江油以北的龙门山断裂为低速异常, 这一深度上沿 着龙门山断裂的地震很少. 在 $10 \mathrm{~km}$ 深度上, 龙门山 西侧的高速异常收玫于灌县-茂汶一带, 汶川以南和 江油以北为低速异常, 四川盆地西部多为低速异常,
汶川附近的地震大都发生在龙门山西侧高速异常的 南部边缘. 在 $15 \mathrm{~km}$ 深度上, 龙门山西侧的高速异常 集中在灌县-茂汶-绵竹一带, 汶川以南和江油以北仍 为低速异常, 四川盆地西部速度略为偏低; 这一深度 上的地震较多, 其中汶川地震的震中位于灌县-茂汶 的高速异常南端, 其余的地震大都沿着龙门山断裂 向东北方向分布. $20 \mathrm{~km}$ 深度上的速度异常与 $15 \mathrm{~km}$ 深度相似，灌县-茂汶-绵竹一带为高速异常，四川盆 地西部的雅安-成都和德阳-江油等地多为低速异常, 沿着龙门山断裂带仍有许多地震，其分布特征与 15 $\mathrm{km}$ 深度基本相同. 在 $30 \mathrm{~km}$ 深度上, 高速异常出现 

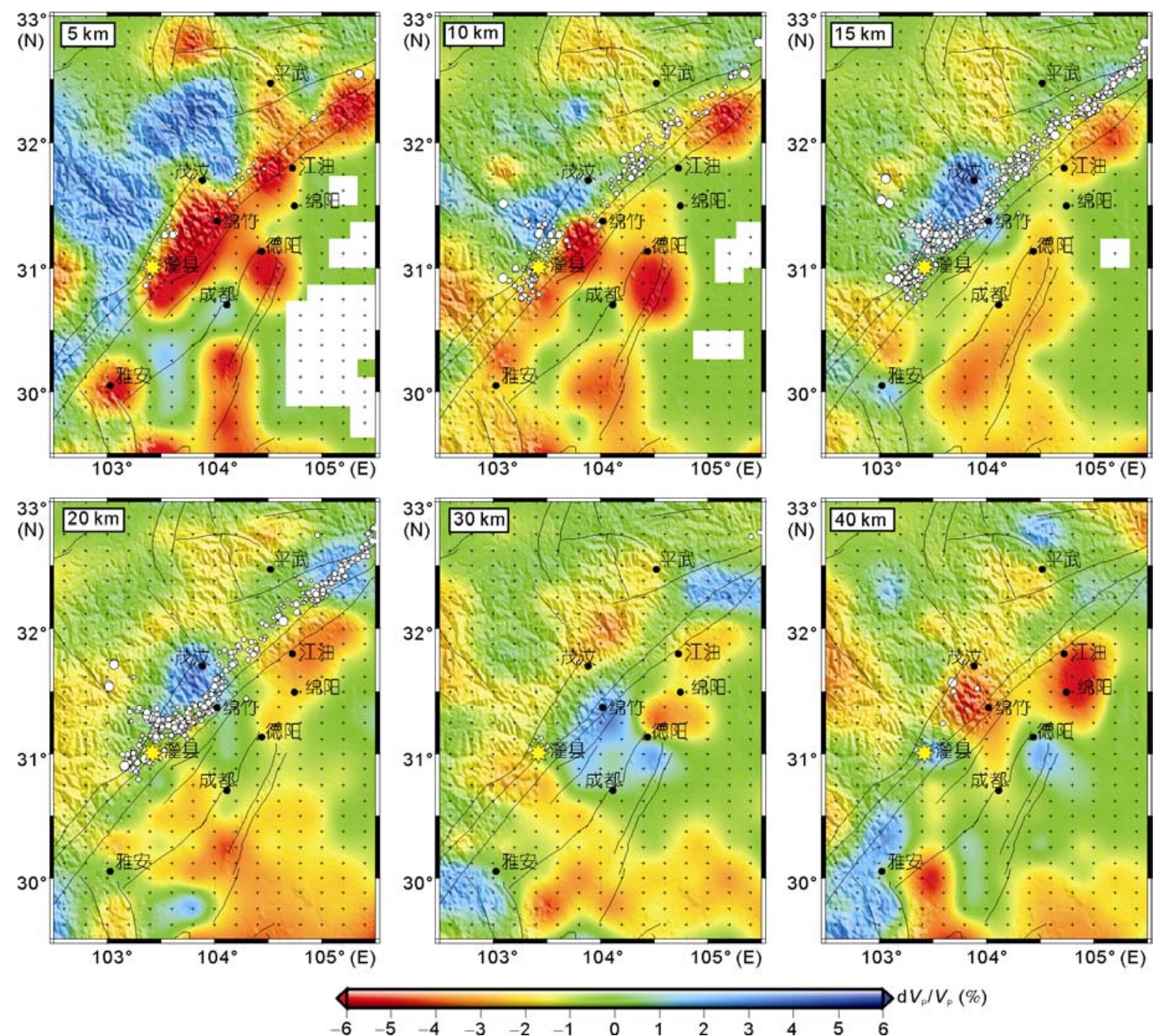

图 5 不同深度的 $\mathbf{P}$ 波速度扰动图像

星号代表汶川 $M_{\mathrm{s}} 8.0$ 地震的位置, 白色圆点代表当前深度 $\pm 5 \mathrm{~km}$ 范围内重新定位后的余震分布, 十字代表反演节点的位置

在四川盆地西部的灌县-绵竹-成都-德阳一带, 其边 界与龙门山断裂带相吻合; 松潘-甘孜造山带、灌县以 南地区和江油-绵竹等地为低速异常, 这个深度上已 经没有地震发生. 在 $40 \mathrm{~km}$ 深度上, 大体上以汶川为 界, 灌县以北至江油的龙门山地区为低速异常, 灌县 以南至雅安的龙门山地区为高速异常, 松潘-甘孜造 山带多为低速异常.

图 6 为穿过龙门山和汶川地震震源区的纵向地 壳速度剖面, 为了便于分析, 仍然将重新定位后的余 震 $^{[1]}$ 投影在剖面上. 从该剖面可以看出, 松潘-甘孜 造山带地壳浅部速度较高, 中下地壳速度偏低且厚 度较大; 而四川盆地的上地壳速度较低, 随着深度的
增加速度逐渐递增且横向变化幅度较小. 速度等值 线的横向变化表明, 四川盆地的低速沉积层向龙门 山逐渐减薄, 龙门山断裂带位于造山带与盆地之间 速度过渡带, 也是基底和莫霍面深度变化最大的区 域, 地震大都发生在其附近 10 20 km 的深度范围内.

\section{3 分析与讨论}

\section{1 汶川地震的深部构造特征}

图 5 和 6 所示的 $\mathrm{P}$ 波速度图像揭示了龙门山断裂 带两侧的地壳结构差异以及汶川地震的深部构造特 征. 在地壳浅部, 松潘-甘孜造山带偏高的 $\mathrm{P}$ 波速度 

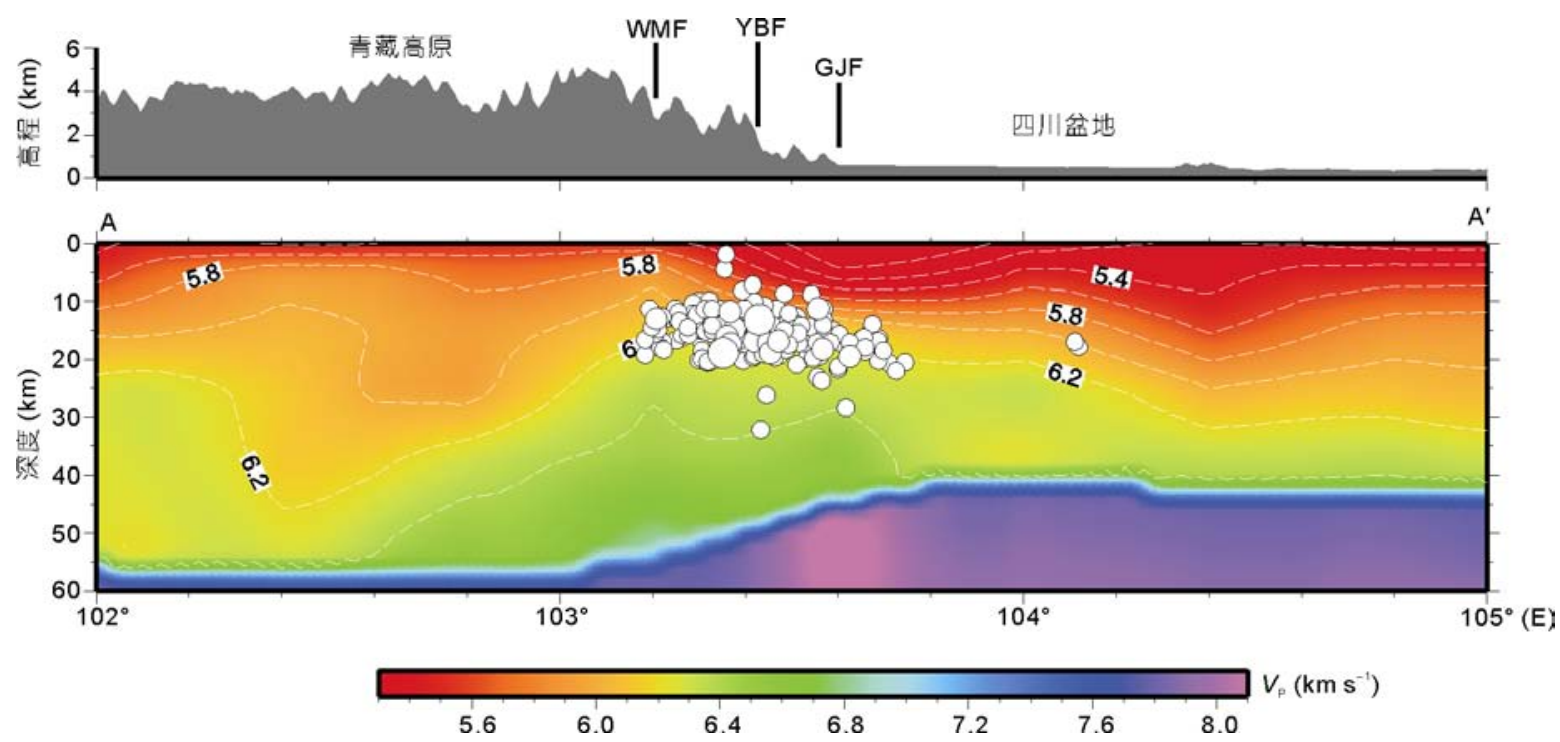

图 6 穿过汶川地震震源区的 $P$ 波速度垂直剖面

WMF, 汶川-茂县断裂; YBF, 映秀-北川断裂; GJF, 灌县-江油断裂; 白色圆点代表沿剖面 $\pm 20 \mathrm{~km}$ 范围内重新定位后的余震在剖面上的投影

与古老基岩的普遍抬升有关; 但是在 10 20 km 的深 度范围内, 龙门山断裂西侧的高速异常体主要集中 在灌县-茂汶一带，与彭灌变质杂岩体的分布范围 ${ }^{[3,4]}$ 相对应, 高速异常体的收玫深度与汶川地震的震源 深度 $(16 \sim 18 \mathrm{~km})^{[1,10]}$ 也是相吻合的, 表明这一地区的 地壳介质具备较高的应变强度, 有利于应力的长期 积累和突然释放. 与此对应, 四川盆地西部的高速异 常区主要分布在龙门山断裂东侧的灌县-绵竹-成都德阳一带, 可以看出汶川地震的发生是松潘-甘孜造 山带和四川盆地两个不同地壳块体相互作用的结果, 其动力学原因则与青藏高原的向东挤出受到四川盆 地刚性岩石层块体的阻挡有关 ${ }^{[25]}$.

汶川地震的破裂起始点以及地震破裂的传播方 向与龙门山断裂带的地壳结构有着紧密的联系. 在 15 20 $\mathrm{km}$ 深度, 无论是龙门山西侧的彭灌高速异常 体, 还是龙门山东侧的四川盆地高速异常, 汶川地震 的震中都位于其靠近龙门山断裂带的南端, 显然这 一现象可归因于青藏东部的地壳向东运动在龙门山 断裂带受阻, 与四川盆地的刚性地壳发生了碰撞, 长 期的挤压使得应力不断积累并且突然释放造成巨大 的地震破裂. 由于汶川以南地壳强度相对较弱(速度 偏低), 估计具备较大的柔韧性不易发生脆性破裂, 故地震破裂沿着汶川以北的彭灌高速异常的边界向 北方向传递, 沿着龙门山断裂带形成长达数百公里 的破裂面 ${ }^{[1]}$.

\section{2 龙门山地壳增厚与构造变形}

地壳缩短与增厚是青藏高原东部深部动力学关 注的焦点之一. 从图 6 所示的纵向地壳速度结构剖面 看出, 以龙门山断裂带为界, 松潘-甘孜造山带的地 壳厚度与四川盆地相比增加了至少 10 余公里, 主要 表现为中下地壳低速层的厚度增加, 这一认识与青 藏高原东部地壳增厚和其横向流动受到四川盆地岩 石层阻挡的动力学模式 ${ }^{[25]}$ 是相一致的.

Clark 和 Royden ${ }^{[25]}$ 根据青藏东部中下地壳较高 的温度和较低的地震波速度, 提出地壳增厚主要发 生在低粘度的中下地壳, 但是 Burchfiel 等 ${ }^{[4]}$ 对于相对 软弱的地壳是否向东延伸到龙门山地区提出质疑, 认为过于软弱的中下地壳难以支撑龙门山陡峭的地 形变化. 近年来的深部地球物理探测表明, 青藏东部 地壳中部电性低阻层的厚度在龙门山下方明显增

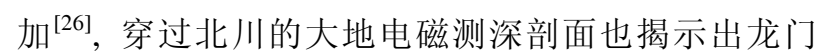
山中下地壳的低电阻特性 ${ }^{[27]}$; 在地震学方面, 王椿 镛等 ${ }^{[6]}$ 和刘启元等 ${ }^{[16]}$ 利用远震接收函数方法分析了 青藏高原东部的地壳上地幔结构, 证实龙门山下方 中下地壳的 $\mathrm{S}$ 波速度偏低, 加之本文以及四川西部和 龙门山地区的地震层析成像结果都发现了类似的特 征 ${ }^{[12,13,15]}$, 这些资料共同印证了青藏高原东部边缘中 下地壳的低强度柔韧性, 对于理解青藏高原东部及 汶川地震的深部动力成因具有重要的地质意义. 
Burchfiel 等 ${ }^{[4]}$ 认为龙门山的断层活动与褶皱构 造和地壳深部的韧性变形有关, 但是对于它们究竟 以何种方式相互作用并不十分明确. 现有地质地球 物理资料 ${ }^{[12,26,27]}$ 与本文的结果表明: 青藏东部在向东 挤出时明显受到四川盆地刚性岩石层块体的阻挡, 使得龙门山基底抬升发生褶皱变形，自西向东形成 一系列逆冲断层和推覆构造, 中下地壳由于具备较 大的柔韧性而发生塑性变形, 垂向物质的增加导致 地壳厚度的增大和莫霍面弯曲下沉. 这一模式印证 了 Burchfiel 等 ${ }^{[4]}$ 提出的地质模型. 汶川地震正是在这 一动力学作用下龙门山断裂应力长期积累产生的结 果, 而地震的破裂起始点和传播方向则与龙门山断 裂带附近的地壳结构组成、应变强度的差异, 特别是 彭灌杂岩体与四川盆地刚性地壳的碰撞有直接关系.

\section{4 结论}

汶川地震的成因与龙门山构造带的地壳结构和 深部动力学性质有密切的关系. 以 $\mathrm{P}$ 波高速异常为特
征的彭灌杂岩体是龙门山断裂带西侧地壳内部应变 强度较大、易于应力长期积累的主要载体, 汶川地震 位于其靠近龙门山断裂带的南端, 该块体与四川盆 地地壳的挤压碰撞是导致地震发生的直接原因. 龙 门山断裂带的地壳结构和应变强度差异决定了地震 的破裂起始点、震源深度以及破裂传播方向：在汶川 以北, 沿着龙门山断裂带的高速异常有利于破裂的 发生和传递, 而汶川以南地壳强度相对较弱, 不易产 生脆性破裂而引发地震, 这是地震破裂自汶川向北 延伸和汶川以南缺少地震活动的重要原因. 汶川地 震的深部动力成因涉及到龙门山断裂带两侧地壳结 构差异, 松潘-甘孜造山带中下地壳强度较弱, 易于 发生韧塑性变形和横向流动. 由于青藏高原的向东 运动受到四川盆地刚性岩石层的阻碍, 使得龙门山 地壳发生垂向变形, 中下地壳厚度明显增加, 莫霍面 向下弯曲下沉, 基底抬升向山前盆地逆冲, 由此引发 的地壳形变和应力积累为汶川地震的发生提供了深 部动力来源.

\section{参考文献}

1 陈九辉, 刘启元, 李顺成, 等. 汶川 $M_{\mathrm{s}} 8.0$ 地震余震序列重新定位及其地震构造研究. 地球物理学报, 2009, 52: 390-397

2 许志琴, 李化启, 侯立玮, 等. 青藏高原东缘龙门山-锦屏造山带的崛起一一型拆离断层和挤出机制. 地质通报, 2007, 26: 1262-1276

3 张培震, 徐锡伟, 闻学泽, 等. 2008 年汶川 8.0 级地震发震断裂的滑动速率、复发周期和构造成因. 地球物理学报, 2008,51 : 1066-1073

4 Burchfiel L H, Royden B C, van der Hilst R D, et al. A geological and geophysical context for the Wenchuan earthquake of 12 May 2008 , Sichuan, People's Republic of China. Geol Soc Am Today, 2008, 18: 4-11

5 楼海, 王椿镛, 吕智勇, 等. 2008 年汶川 $M_{\mathrm{s}} 8.0$ 级地震的深部构造环境——远震 $\mathrm{P}$ 波接收函数和布格重力异常的联合解释. 中国科学 D 辑: 地球科学, 2008, 38: 1207-1220

6 王椿镛, 楼海, 吕智勇, 等. 青藏高原东部地壳上地幔 S 波速度结构一下地壳流的深部环境. 中国科学 $\mathrm{D}$ 辑: 地球科学, 2008, 38: 22-32

7 张培震. 青藏高原东缘川西地区的现今构造变形、应力分配与深部动力学过程. 中国科学 $\mathrm{D}$ 辑: 地球科学, 2008, 38: 1041-1056

8 Molnar P, Gipson J M. A bound on the rheology of continental lithosphere using very long baseline interferometry: The velocity of South China with respect to Eurasia. J Geophys Res, 1996, 101: 545-553

9 Royden L H, Burchfiel B C, King R W, et al. Surface deformation and lower crustal flow in eastern Tibet. Science, 1997, 276: 788-790

10 黄媛, 吴建平, 张天中, 等. 汶川 8.0 级大地震及其余震序列重新定位研究. 中国科学 D 辑: 地球科学, 2008, 38: 1250-1257

11 王卫民, 赵连锋, 李娟, 等. 四川汶川 8.0 级地震震源过程. 地球物理学报, 2008, 51: 1403-1410

12 胥䝠, 黄润秋, 李志伟, 等. 龙门山构造带及汶川震源区的 S 波速度结构. 地球物理学报, 2009, 52: 329-338

13 吴建平, 黄媛, 张天中, 等. 汶川 $M_{\mathrm{s}} 8.0$ 级地震余震分布及周边区域 $\mathrm{P}$ 波三维速度结构研究. 地球物理学报, 2009, 52: 320-328

14 郭飙, 刘启元, 陈九辉, 等. 川西龙门山及邻区地壳上地幔远震 P 波层析成像. 地球物理学报, 2009, 52: 346-355 
15 雷建设, 赵大鹏, 苏金蓉, 等. 龙门山断裂带地壳精细结构与汶川地震发震机理. 地球物理学报, 2009, 52: 339-345

16 刘启元, 李昱, 陈九辉, 等. 汶川 $M_{\mathrm{s}} 8.0$ 地震: 地壳上地幔 $\mathrm{S}$ 波速度结构的初步研究. 地球物理学报, 2009, 52: 309-319

17 江为为. 调和级数法与重力资料反演地壳构造. 中国科技大学研究生院学报, 1989, 6: 96-104

18 Hao T Y, Xu Y, Suh M, et al. East marginal fault of the Yellow Sea: A part of the conjunction zone between Sino-Korea and Yangtze Block? Geol Soc London Spec Publ, 2007, 280: 281-292

19 Jiang X, Jin Y. Maping the deep lithospheric structure beneath the eastern margin of the Tibetan Plateau from gravity anomalies. J Geophys Res, 2005, 110: B07407, doi: 10.1029/2004JB003394

20 Huang J, Zhao D, Zheng S. Lithospheric structure and its relationship to seismic and volcanic activity in southwest China. J Geophys Res, 2002, 107(B10): 2255, doi: 10.1029/2000JB000137

21 王椿镛, 吴建平, 楼海, 等. 川西藏东地区的地壳 P 波速度结构. 中国科学 D 辑: 地球科学, 2003, 33(增刊): 181-189

22 Um J, Thurber C H. A fast algorithm for two-point seismic ray tracing. Bull Seismol Soc Am, 1987, 77: 972-986

23 Zhao D, Hasegawa A, Horiuchi S. Tomographic imaging of P and S wave velocity structure beneath northeastern Japan. J Geophys Res, 1992, 97: 19909-19928

24 Koketsu K, Sekine S. Pseudo-bending method for three-dimensional seismic ray tracing in a spherical earth with discontinuities. Geophys J Int, 1998, 132: 339-346

25 Clark M K, Royden L H. Topographic ooze: Building the eastern margin of Tibet by lower crustal flow. Geology, 2000, 28: 703-706

26 赵国泽, 陈小斌, 王立风, 等. 青藏高原东边缘地壳“管流”层的电磁探测证据. 科学通报, 2008, 53: 345-350

27 王绪本, 朱迎堂, 赵锡奎, 等. 青藏高原东缘龙门山逆冲构造深部电性结构特征. 地球物理学报, 2009, 52: 564-571 